\title{
PERAN MEDIASI CITRA MEREK DALAM MEMBENTUK HUBUNGAN ANTARA KUALITAS PRODUK TERHADAP LOYALITAS PELANGGAN (STUDI PENGGUNA PRODUK TELKOMSEL DI KOTA BOGOR)
}

\author{
Anugerah Dachi \\ STIE Manajemen Bisnis Indonesiab-bDepok, Indonesia \\ E-mail : anugerahdachi@gmail.com
}

\begin{abstract}
Abstrak
Tujuan penelitian ini adalah untuk melakukan analisis tentang pengaruh antara kualitas produk dan citra merek terhadap loyalitas pelanggan pengguna produk Telkomsel di kota Bogor.. Disamping itu juga untuk mengetahui peran mediasi citra merek antara kualitas produk terhadap loyalitas pelanggan pengguna produk Telkomsel di Kota Bogor Metode Penelitian dalam penelitian ini adalah metode kuantitatif. Teknik analisis data menggunakan Structural Equation Modeling dengan diolah menggunakan Software Amos versi 23. Populasi dalam penelitian ini adalah pengguna produk Telkomsel yang berada di Kota Bogor. Pengambilan sampel dilakukan dengan metode non probability sampling yaitu dengan teknik purposive sampling. Penulis berhasil mengumpulkan kuisioner sebanyak 208 responden, sehingga sampel dalam penelitian sebanyak 208 responden. Hasil penelitian menunjukkan bahwa kualitas dari suatu produk yang diproduksi oleh Telkomsel dan citra merek memiliki keterkaitan ataupun pengaruh terhadap loyalitas pelanggan. Ditemukan juga bahwa citra merek mampu memediasi pengaruh antara kualitas produk terhadap loyalitas pelanggan. Penulis memberikan saran untuk terus meningkakan kualitas produk dan citra merek dari produk Telkomsel. Hal ini dapat dilakukan dengan terus memperhatikan keluhan pelanggan dan mengatasi dengan baik.
\end{abstract}

Kata Kunci : Kualitas Produk, Citra Merek, dan Loyalitas Pelanggan.

\section{PENDAHULUAN}

Telkomsel merupakan perusahaan telekomunikasi selular yang memiliki visi memberikan layanan dan solusi gaya hidup digital mobile kelas dunia yang terpercaya. Berdasarkan laporan kinerja keuangan Telkomsel (www.telkomsel.com) pada tahun 2018 menunjukkan bahwa pendapat pada segmen mobile sebesar Rp. 89,2 triliun, pada tahun 2017 sebesar Rp. 93.2 triliun, pada tahun 2016 sebesar Rp. 86,7 triliun. Hal ini menunjukkan bahwa ada kenaikan jika dibandingkan dengan tahun 2016, namun jika dibandingkan dengan pendapatan tahun 2017, pendapatan telkomsel pada tahun 2018 mengalami penurunan.

Salah satu indikator kemajuan perusahaan adalah meningkatkatnya pendapatan perusahaan. Telkomsel yang dalam menjalankan bisnis berbasis layanan, tentu saja tidak bisa terlepas dari loyalitas konsumen dalam menjalankan bisnisnya. Loyalitas pelanggan memiliki peran yang sangat penting untuk kemajuan perusahaan. Para konsumen melakukan pembelian bukan hanya sekedar 
membutuhkan barang yang diinginkan, akan tetapi ada sesuatu yang mereka tampilkan dalam melayani publiknya, image dibentuk berdasarkan pengalaman yang dialami oleh seseorang terhadap sesuatu, sehingga akhirnya dipakai untuk melakukan pembelian. Merek merupakan masalah utama dalam strategi produk karena, biasanya merek menempel pada produk, ibarat orang dengan namanya (Sastha P \& Wardhana, 2016).

Penelitian berkaitan dengan loyalitas pelanggan telah banyak dilakukan oleh para peneliti sebelumnya. Produk dan citra merek merupakan salah satu faktor yang mempengaruhi loyalitas pelanggan. Seperti penelitian yang dilakukan oleh Wijayanto \& Iriani, (2013) dan Sastha P \& Wardhana, (2016) menunjukkan bahwa citra merek mempengaruhi loyalitas pelanggan. Penelitian tentang kualitas produk terhadap loyalitas pelanggan perndah dilakukan oleh Khoironi, Syah, \& Dongoran, (2018), membuktikan bahwa adanya pengaruh kualias produk terhadap loyalitas pelanggan. Hasil penelitian yang berbeda ditemukan oleh Kusumasasti et al., (2014) yang dalam penelitianya menyimpulkan bahwa kualitas produk tidak berpengaruh signifikan terhadap loyalitas pelanggan. Disamping mempengaruhi loyalitas pelanggan, kualitas produk juga mempengaruhi citra merek, sebagaimana hasil penelitian oleh Sihabudin, (2015), dalam penelitiannya menyimpulkan bahwa bahwa kualitas produk mempengaruhi citra merek.

Berdasarkan latar belakang tersebut, penulis merumuskan pertanyaan penelitian dalam penelitian ini adalah sebagai berikut :

1. Apakah kualitas produk mempengaruhi citra merek produk Telkomsel di kota Bogor?

2. Apakah kualitas produk mempengaruhi loyalitas pelanggan pengguna produk Telkomsel di kota Bogor.

3. Apakah citra merek mempengaruhi loyalitas pelanggan pengguna produk Telkomsel di kota Bogor.

\section{KAJIAN TEORI}

\section{Loyalitas Pelanggan}

Lovelock, et al., (2011) mendefinisikan bahwa loyalitas merupakan perilaku yang menunjukkan ataupun mencerminkan adanya pembelian secara berulang dan merekomendasikan produk perusahaan tersebut kepada orang lain. Menurut Griffin, (2002) loyalitas berarti adanya suatu perilaku seperti melakukan pembelian rutin atas suatu produk perusahaan. Ditambahkan juga oleh Kotler (dalam Wijayanto \& Iriani, 2013) menyatakan bahwa konsumen ataupu pelanggan yang loyal tidak hanya diukur dari berapa banyak pelanggan tersebut melakukan pembelian, tapi dari berapa sering pelanggan tersebut melakukan pembelian ulang, dan juga merekomendasikan produk tersebut kepada orang lain seperti kepada teman, orangtua dan lain-lain. Pendapat lain juga menjelaskan bahwa loyalitas bermakna sejauh mana pelanggan menunjukkan perilaku pembelian berulang dari penyedia layanan, menunjukkan persepsi dan sikap yang positif terhadap penyedia layanan, dan sehingga akan selalu mempertimbangkan untuk menggunakan layanan dari perusahaan tersebut jika pelanggan membutuhkannya (Hengestu \& Iskandar, 2017).

\section{Kualitas Produk}

Pengertian kualitas produk menurut Kotler \& Keller, (2012) adalah kemamuan produk tersebut dalam memberikan hasil atau kinerja yang sesuai atau bahkan dapat melebihi ekpektasi dari 
pelanggan. Tjiptono, (2012) juga memberikan penjelasan bahwa kualitas suatu produk yang memberikan gambaran langsung kepada konsumen dari suatu produk tersebut seperti kinerja produk, keandalan produk, produk tersebut mudah untuk digunakan, produk tersebut memiliki estetika dan sebagainya. Dalam pengertian yang lain, kualitas dapat juga diartikan sebagai sesuatu yang mampu memenuhi segala keinginan atau kebutuhan pelanggan. Menurut Boyd ( dalam Ridho \& Suharyono, 2017) adapun faktor-faktor yang berkaitan dengan penilaian pelanggan ataupun konsumen tentang produk adalah sebagai berikut:

1. Kinerja produk yang terwujud melalui karakteristik pengoperasian dasar suatu produk,

2. Tampilan atau karakteristik produk tambahan yang dirancang untuk memperkuat fungsi produk,

3. Daya tahan dari produk tersebut, dan

4. Persepsi pelanggan tentang mutu dari produk tersebut.

Sedangkan menurut Tjiptono, (2012) mengemukan bahwa dimensi dari kualitas produk adalah kinerja produk, ciri-ciri atau keistimewaan tambahan, kesesuaian dengan spesifikasi, keandalan, daya tahan, estetika, kualitas yang dipersepsikan, kemudahan perbaikan.

\section{Citra Merek}

Citra merek berhubungan dengan sikap yang berupa keyakinan dan preferensi terhadap suatu merek (Sihabudin, 2015). Menurut Kotler dan Amstrong, 2001 (dalam Wijayanto \& Iriani, 2013) citra merek adalah seperangkat keyakinan konsumen mengenai merek tertentu. Keller (dalam (Sastha P \& Wardhana, 2016) menjelaskan bahwa citra merek dibangun dari favorability, strength, dan uniqueness. Suatu merek produk akan tercermin dan dilihat oleh konsumen melalui citra yang terbangun dalam produk merek tersebut, baik kesan positif maupun kesan negatif. Semakin kuat kesan positifsebuah merek produk dalam benak konsumen, maka konsumen cenderung akan lebih konsisten dalam mengkonsumsi suatu merek tertentu(Hengestu \& Iskandar, 2017)

\section{Pengaruh Kualitas Produk dan Citra Merek terhadap Loyalitas Pelanggan}

Hasil penelitian yang dilakukan oleh Sastha P \& Wardhana, (2016) menunjukkan bahwa citra merek mempengaruhi loyalitas pelanggan pengguna kartu Simpati di Denpasar. Penelitian yang lain oleh Khoironi, Syah, \& Dongoran, (2018) juga menunjukkan bahwa kualitas produk dan citra merek memiliki pengaruh yang positif dan signifikan terhadap loyalitas pelanggan. Disamping itu, hasil penelitian yang dilakukan oleh Sihabudin, (2015) menunjukkan bahwa kualitas produk mempengaruhi citra merek. Dengan demikian, berdasarkan temuan penelitian sebelumnya, dapat dijelaskan bahwa kualitas produk dan citra merek memiliki peran pentin dalam meningkatkan loyalitas pelanggan. Artinya semakin bagus kualias produk dan citra merek produk Telkomsel semakin bagus, maka pelanggan akan cenderung memiliki loyalitas yang tinggi atas produk tersebut. Sebaliknya apabila kualitas produk dan citra merek semakin tidak baik, maka pelanggan akan memiliki loyalitas yang rendah. Disamping itu, kualitas produk juga menjadi prediktor dari citra merek. Artinya citra merek dari produk Telkomsel tersebut akan ditentukan oleh kualitas produk dari Telkomsel itu sendiri. Semakin bagus kualitas produk, citra merek akan meningkat, sebaliknya semakin tidak bagus kualitas produk maka citra merek bagi pelanggan produk Telkomsel di Kota Bogor akan semakin kurang baik. 
Kerangka Konseptual penelitian dapat digambarkan sebagai berikut :

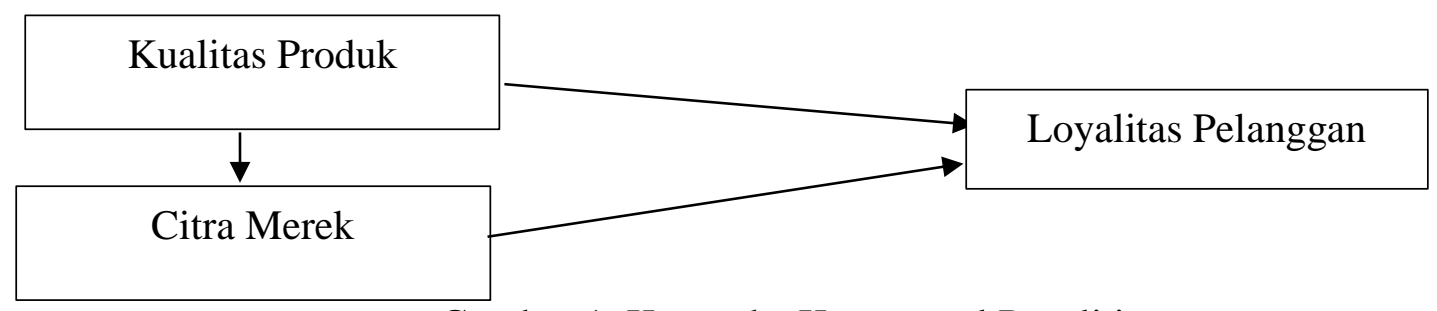

Gambar 1. Kerangka Konseptual Penelitian

\section{METODE PENELITIAN}

Penelitian ini dilakukan dengan pendekatan metode kuantitatif dengan menggunakan Structural Equation Modeling. Populasi dalam penelitian ini adalah pengguna produk Telkomsel di Kota Bogor. Pengambilan sampel dilakukan dengan metode non probability sampling yaitu dengan teknik purposive sampling, asalan peneliti dalam menggunakan teknik ini dilakukan karena jumlah populasi dalam penelitian ini tidak diketahui jumlahnya secara pasti. Penulis berhasil mengumpulkan kuisioner sebanyak 208 responden, sehingga sampel dalam penelitian sebanyak 208 responden. Dalam penelitian ada tiga variabel yang akan digunakan yaitu loyalitas pelanggan, kualitas produk, dan citra merek. Pengukuran loyalitas pelanggan dalam penelitian ini menggunakan enam item pertanyaan yang dikembangkan dari empat dimenasi loyalitas pelanggan yaitu cognitive loyalt, affective loyalty, conative loyalty, dan action loyalty (Bobâlcă, et al.,2012). Citra merek diukur dengan tiga dimensi yaitu dimensi keunggulan assosiasi merek, ,dimensi kekuatan asosiasi merek, dimensi keunikan asosiasi merek (Keller, 2013). Dimensi pada setiap citra merek tersebut dikembangkan menjadi lima item pernyataan. Kualitas produk diukur dengan empat item pernyataan yang diadopsi dari dimensi yang dikemukakan oleh (Tjiptono, 2012). Dalam penelitian ini penulis menggunakan empat dimensi yaitu kinerja produk, keandalan, daya tahan, dan estetika.

\section{Tabel 1. Pengukuran Variabel Penelitian}

\begin{tabular}{|c|c|}
\hline Variabel & Indikator/Item pernyataan \\
\hline \multirow{6}{*}{$\begin{array}{l}\text { Loyalitas } \\
\text { Pelanggan } \\
\text { (Bobâlcă et al., } \\
\text { 2012) }\end{array}$} & $\begin{array}{l}\text { Untuk alat komunikasi, saya lebih menyukai produk dari Telkomsel } \\
\text { daripada produk lain }\end{array}$ \\
\hline & Saya merasa sangat senang menggunakan produk telkomsel \\
\hline & Saya membeliki produk Telkomsel karena saya sangat menyukainya \\
\hline & Saya akan terus membeli produk telkomsel untuk kedepannya. \\
\hline & Saya merekomendasikan produk Telkomsel kepada orang lain \\
\hline & $\begin{array}{l}\text { Saya menyampaikan hal-hal yang positif tentang produk Telkomsel kepada } \\
\text { orang lain }\end{array}$ \\
\hline
\end{tabular}




\begin{tabular}{|l|l|}
\hline $\begin{array}{l}\text { Kualitas Produk } \\
\text { (Tjiptono, 2012) }\end{array}$ & $\begin{array}{l}\text { Produk dari telkomsel memiliki kecepatan, kemudahan dan kenyamanan } \\
\text { dalam penggunaannya. }\end{array}$ \\
\cline { 2 - 2 } & $\begin{array}{l}\text { Produk telkomsel memiliki keandalan yang sangat baik, tidak mudah rusak } \\
\text { atau gagal digunakan. }\end{array}$ \\
\cline { 2 - 2 } & Produk telkomsel memiliki daya tahan yang lama \\
\cline { 2 - 2 } & Fitur dan desain produk telkomsel sangat menarik \\
\hline $\begin{array}{l}\text { Citra Merek } \\
\text { (Keller, 2013) }\end{array}$ & Merek yang diproduksi oleh telkomsel mudah untuk didapatkan \\
\cline { 2 - 2 } & Telkomsel memiliki merek yang terpercaya \\
\cline { 2 - 2 } & Merek yang diproduksi telkomsel sangat kuat dibenak konsumen \\
\cline { 2 - 2 } & Merek yang diproduksi oleh Telkomsel memberikan manfaat lebih \\
\cline { 2 - 2 } & Merek yang diproduksi oleh telkomsel mudah dikenali \\
\hline
\end{tabular}

\section{TEMUAN PENELITIAN}

\section{Uji Normalitas}

Uji normalitas merupakan bentuk pengujian yang bertujuan untuk mengetahui apakah data dalam suatu variabel penelitian tersebar secara normal atau dengan kata lain, data diambil dari populasi yang normal. Pada Structural Equation Modeling, salah satu persyaratan yang harus dipenuhi adalah normalitas data adalah data harus terdistribusi secara normal. Hasil uji normalitas menunjukkan bahwa data dalam penelitian ini terdistribusi seara normal. Hal ini terlihat dari nil $\mathrm{cr}< \pm 2.58$. Nilai skewness and kurtosis dari semua indikator berada dibawah < 2.58 (Schumacker \& Lomax, 2010).

Tabel 2. Uji Normalitas

\begin{tabular}{|l|rrrrrr|}
\hline Variable & $\min$ & $\max$ & skew & c.r. & kurtosis & c.r. \\
\hline LoyaP6 & 1,000 & 5,000 &,- 090 &,- 529 &,- 405 & $-1,192$ \\
LoyaP5 & 1,000 & 5,000 &,- 200 & $-1,176$ &,- 261 &,- 770 \\
LoyaP4 & 1,000 & 5,000 &,- 023 &,- 138 &,- 437 & $-1,285$ \\
LoyaP3 & 2,000 & 5,000 &,- 126 &,- 739 &,- 734 & $-2,160$ \\
LoyaP2 & 2,000 & 5,000 &, 070 &, 410 &,- 566 & $-1,666$ \\
LoyaP1 & 2,000 & 5,000 &,- 115 &,- 678 &,- 916 & $-2,697$ \\
CM1 & 2,000 & 5,000 &,- 024 &,- 141 &,- 846 & $-2,490$ \\
CM2 & 2,000 & 5,000 &,- 042 &,- 249 &,- 610 & $-1,796$ \\
CM3 & 2,000 & 5,000 &,- 179 & $-1,055$ &,- 476 & $-1,400$ \\
CM4 & 2,000 & 5,000 &,- 008 &,- 045 &,- 492 & $-1,449$ \\
CM5 & 1,000 & 5,000 &, 169 &, 996 &,- 297 &,- 875 \\
KP4 & 2,000 & 5,000 &, 019 &, 111 &,- 604 & $-1,778$ \\
KP3 & 1,000 & 5,000 &,- 239 & $-1,406$ &,- 449 & $-1,323$ \\
\hline
\end{tabular}




\begin{tabular}{|l|rrrrrr|}
\hline Variable & $\min$ & $\max$ & skew & c.r. & kurtosis & c.r. \\
\hline KP2 & 2,000 & 5,000 &,- 076 &,- 449 &,- 631 & $-1,859$ \\
KP1 & 2,000 & 5,000 &,- 210 & $-1,236$ &,- 361 & $-1,062$ \\
Multivariate & & & & & 5,657 & 1,806 \\
\hline
\end{tabular}

Berdasarkan Tabel di atas menunjukkan bahwa data dalam penelitian berdistribusi secara normal. Hal ini terlihat dari nilai cr 1.806 , artinya nilai tersebut berada dibawah $< \pm 2.58$. Sehinga dapat disimpulkan data berdistribusi normal.

\section{Model Pengukuran}

Model pengukuran dilakukan untuk mengetahui sejauhmana bentuk hubungan antara variabel manifest atau indikator dengan variabel latennya. Nilai faktor loading diharahapkan lebih besar 0.50, nilai CR (composite reliablity) direkomendasikan $\geq 0.70$ dan AVE (average variance extracted) $\geq$ 0,50. Hasil analisis model pengukuran dapat dilihat pada Tabel dibawah ini:

Tabel 3. Model Pengukuran

\begin{tabular}{|c|c|c|c|c|c|c|}
\hline Indikator & $\begin{array}{c}\text { Factor } \\
\text { Loading }\end{array}$ & $\begin{array}{c}\text { Kuadrat Factor } \\
\text { Loading }\end{array}$ & Error & CR & AVE & Keterangan \\
\hline LoyaP1 & 0,704 & 0,496 & 0,504 & 0.886 & 0.565 & \multirow{6}{*}{$\begin{array}{l}\text { Valid dan } \\
\text { Reliabel }\end{array}$} \\
\hline LoyaP2 & 0,780 & 0,608 & 0,392 & & & \\
\hline LoyaP3 & 0,759 & 0,576 & 0,424 & & & \\
\hline LoyaP4 & 0,744 & 0,554 & 0,446 & & & \\
\hline LoyaP5 & 0,819 & 0,671 & 0,329 & & & \\
\hline LoyaP6 & 0,699 & 0,489 & 0,511 & & & \\
\hline KP1 & 0,728 & 0,470 & 0,530 & 0,830 & 0,548 & \multirow{4}{*}{$\begin{array}{l}\text { Valid dan } \\
\text { Reliabel }\end{array}$} \\
\hline KP2 & 0,733 & 0,463 & 0,537 & & & \\
\hline KP3 & 0,738 & 0,455 & 0,545 & & & \\
\hline KP4 & 0,764 & 0,416 & 0,584 & & & \\
\hline CM1 & 0,74 & 0,548 & 0,452 & 0,865 & 0,561 & \multirow{5}{*}{$\begin{array}{l}\text { Valid dan } \\
\text { Reliabel }\end{array}$} \\
\hline CM2 & 0,778 & 0,605 & 0,395 & & & \\
\hline CM3 & 0,74 & 0,548 & 0,452 & & & \\
\hline CM4 & 0,781 & 0,610 & 0,390 & & & \\
\hline CM5 & 0,705 & 0,497 & 0,503 & & & \\
\hline
\end{tabular}

Sumber : Data diolah, 2020.

\subsection{Uji Kecocoka Model}

Persyaratan selanjutnya dalam pengujianya SEM adalah uji kesesuaian atau kecocokan model. Beberapa kriteria dalam pengujian kesesuaian model adalah Adjusted GFI (AGFI) > 0.90, 
Goodness of Fit Index (GFI) > 0.90, CFI > 0.90, TLI > 0.90, RMSEA $<0.08$, and RMR $<0.05$ (Hair et al, 2017). Hasil uji kesesuaian model dapat dilihat pada Tabel 3.

Tabel 4. Uji Kesesuaian Model

\begin{tabular}{|l|c|c|}
\hline \multicolumn{1}{|c|}{ riteria } & Hasil & Keputusan \\
\hline P-Value & $\mathbf{0 . 0 5 4}$ & Good Fit \\
\hline Cmin/DF & 1.256 & Good Fit \\
\hline Adjusted Goodness of Fit (AGFI) & 0.909 & Good Fit \\
\hline The goodness of Fit Index (GFI) & 0.934 & Good Fit \\
\hline Comparative Fit Index (CFI) & 0.985 & Good Fit \\
\hline Tucker Lewis Index (TLI) & 0.982 & Good Fit \\
\hline Root Mean Square Error of Approximation (RMSEA) & 0.035 & Good Fit \\
\hline Root Mean Square Residual (RMSR) & 0.030 & Good Fit \\
\hline
\end{tabular}

Sumber : Data diolah, 2020.

\subsection{Uji Hipotesis}

Menurut Byrne (2010) keputusan hipotesis diterima apabila nilai critical ratio > 1.96 dan nilai sig. probability lebih kecil dari 0.05. Hasil uji Hipotesis dapat dilihat pada Tabel berikut ini :

Tabel 4.Hasil Uji Hipotesis

\begin{tabular}{|c|c|c|c|c|c|c|}
\hline & & $\begin{array}{c}\text { Standardize } \\
\text { Regression } \\
\text { Weight }\end{array}$ & S.E. & C.R. & $\mathrm{P}$ & Label \\
\hline Citra_Merek & <--- Kualitas_Produk & ,514 &, 105 & 5,820 & $* * *$ & par_12 \\
\hline Loyalitas_Pelanggar & <--- Kualitas_Produk & ,217 & ,094 & 2,702 & ,007 & par_9 \\
\hline Loyalitas_Pelanggar & <--- Citra_Merek &, 575 & 091 & 6,185 & $* * *$ & par_10 \\
\hline
\end{tabular}

Sumber : Data diolah, 2020

Hasil pengujian hipotesis dapat dijelaskan sebagai berikut :

\section{Uji Hipotesis 1}

Hasil penelitian menunjukkan bahwa kualiats produk berpengaruh positif dan signifikan terhadap citra merek produk Telkomsel di Kota Bogor. Hal ini terlihat dari koefisien regresi sebesar 0.514 dengan nilai t hitung (CR) 5,820>1,96 pada signifikansi sebesar 0.000. Dengan demikian dapat dijelaskan bahwa kualitas produk mempengaruhi citra merek produk Telkomsel secara positif dan signifikan. 


\section{Uji Hipotesis 2}

Hasil penelitian menunjukkan bahwa kualiats produk berpengaruh positif dan signifikan terhadap loyalitas pengguna produk Telkomsel di Kota Bogor. Hal ini terlihat dari koefisien regresi sebesar 0.217 dengan nilai thitung (CR) 2,702 > 1,96 pada signifikansi sebesar 0.007. Dengan demikian dapat dijelaskan bahwa kualitas produk mempengaruhi loyalitas pengguna produk Telkomsel secara positif dan signifikan.

\section{Uji Hipotesis 3}

Hasil penelitian menunjukkan bahwa citra merek berpengaruh positif dan signifikan terhadap loyalitas pengguna produk Telkomsel di Kota Bogor. Hal ini terlihat dari koefisien regresi sebesar 0.575 dengan nilai thitung (CR) 6,185 > 1,96 pada signifikansi sebesar 0.000. Dengan demikian dapat dijelaskan bahwa citra mempengaruhi loyalitas pengguna produk Telkomsel secara positif dan signifikan.

\section{Pembahasan}

Penelitian merupakan kajian tentang loyalitas pelanggan pengguna produk Telkomsel di Kota Bogor. Dalam penelitian ini terdapat tiga hipotesis yang dikembangkan berdasarkan kajian teoritis yang diuraikan. Hasil penelitian menunjukkan bahwa semua hipotesis yang diajukan dalam penelitian ini terbukti atau diterima. Kualitas produk, citra merek terbukti menjadi prediktor untuk loyalitas pelanggan pengguna produk Telkomsel di Kota Bogor. Kualitas produk juga menjadi prediktor untuk citra merek. Hasil penelitian menunjukkan bahwa terdapat pengaruh positif dan signifikan antara kualitas produk terhadap citra merek dengan koefisien regresi antara kualitas produk terhadap citra merek sebesar 0,514 atau sebesar 51,4\%. Hal ini berarti semakin tinggi kualitas produk maka citra merek akan semakin bagus bagi pengguna produk telkomsel di Kota Bogor. Sebaliknya semakin kurang bagus kualitas produk, maka citra merek akan semakin kurang bagus bagi pengguna produk telkomsel di Kota Bogor.

Selanjutanya, kualitas produk berpengaruh positif dan signifikan terhadap loyalitas pelanggan pengguna produk telkomsel di Kota Bogor. Diporoleh koefisien regresi sebesar 0,217 atau 21,7\%. Dengan kata lain, semakin bagus kualitas produk, maka secara langsung akan meningkatkan loyalitas pelanggan. Sebaliknya apabila kualitas produk rendah, maka loyalitas pelanggan akan menurun. Hasil penelitian ini diperkuat dengan penelitian yang pernah dilakukan oleh (Khoironi et al., 2018) yang menunjukkan bahwa kualitas produk mempengaruhi loyalitas pelanggan. Hasil penelitin yang dilakukan oleh Lestari \& Yulianto, (2018) juga menunjukkan bahwa kualitas berpengaruh signifikan terhadap loyalitas pelanggan Citra Kendedes Cake \& Bakery di Kota Malang.

Pengaruh antara citra merek terhadap loyalitas pelanggan pengguna produk telkomsel di Kota Bogor memiliki koefisien regersi sebesar 0,575. Hal ini menunjukkan bahwa citra merek memiliki kontribusi sebesar 57,5\% terhadap loyalitas pelanggan. Koefisien regresi memiliki koefisien yang positif. Hal ini berarti pengaruh antara citra merek terhadap loyalitas pelanggan adalah positif. Dengan kata lain, semakin bagus citra merek dari telkomsel, hal ini akan meningkatkan loyalitas pelanggan. Hasil penelitian ini sesuai dengan hasil penelitian yang dilakukan oleh Hengestu \& Iskandar, (2017) dan (Khoironi et al., 2018) yang dalam penelitiaanya menyimpulkan bahwa citra 
merek mempengaruhi loyalitas pelanggan. Wijayanto \& Iriani, (2013) dalam penelitiannya juga menemukan bahwa citra merek berpengaruh positif terhadap loyalitas pelanggan.

Hasil penelitian juga menunjukkan bahwa citra merek memiliki pengaruh yang paling besar terhadap loyalitas pelanggan. Hal ini berarti bahwa citra merek memiliki peran yang sangat penting dalam meningkatkan loyalitas pelanggan pengguna produk telkomsel di Kota Bogor. Disamping itu pengaruh langsung kualitas produk terhadap loyalitas pelanggan $(21,7 \%)$ lebih kecil dibandingkan dengan pengaruh tidak langsung kualias produk melalui citra merek terhadap loyalitas pelanggan (29,6\%. Hal ini berarti karena pengaruh tidak langsung memiliki pengaruh yang paling besar daripada pengaruh tidak langsungnya, maka dapat dinyatakan bahwa citra merek dalam penelitian berperan sebagai mediator yang membentuk hubungan antara kualitas produk terhadap loyalitas pelanggan pengguna produk telkomsel di Kota Bogor.

Model persamaan struktual dapat dilihat pada gambar dibawah ini :

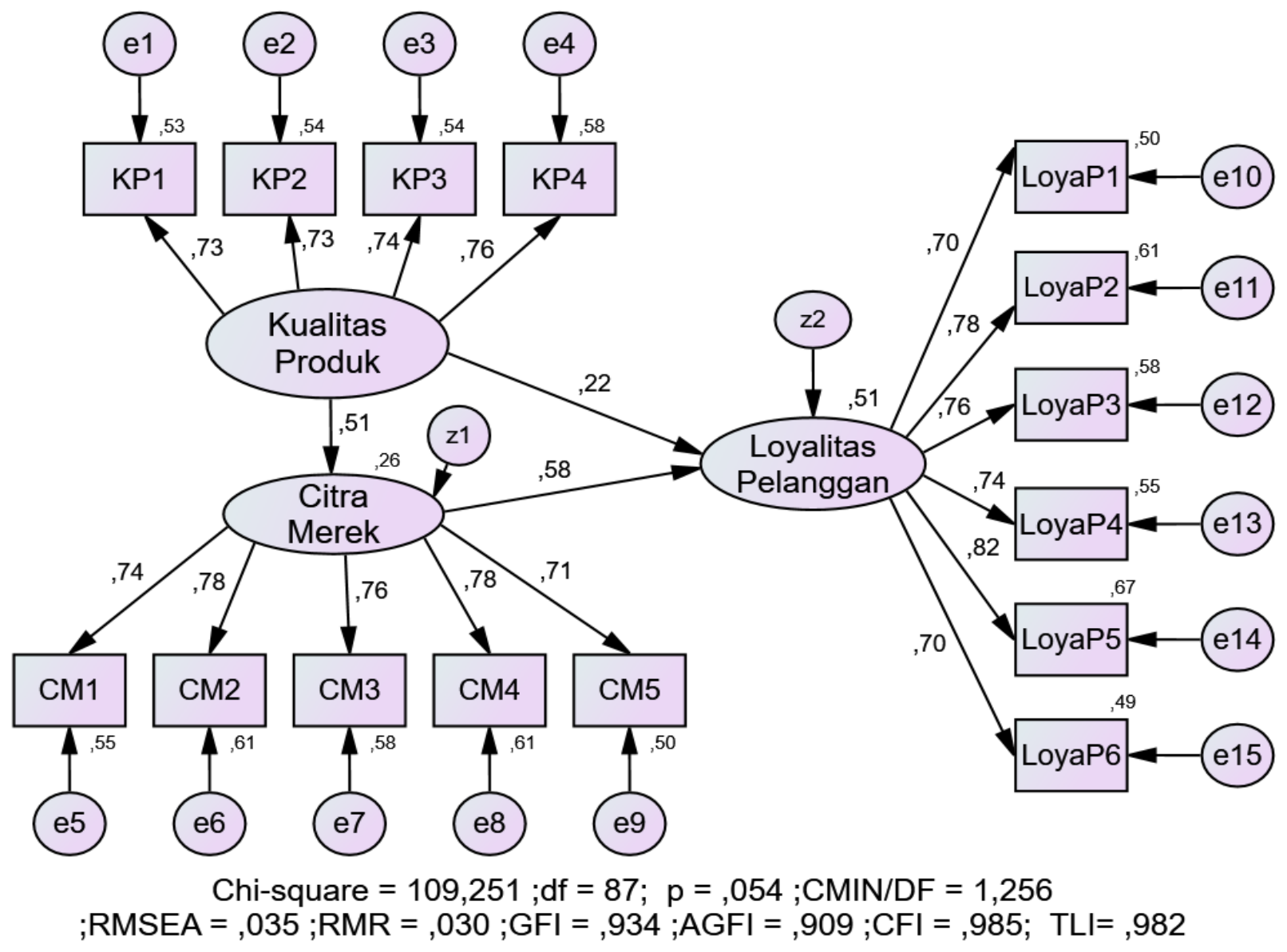

Gambar 2. Model Persamaan Struktural

\section{KESIMPULAN DAN SARAN}




\section{Kesimpulan}

Hasil penelitian menunjukkan bahwa loyalitas pelanggan pengguna produk telkomsel di Kota Bogor di pengaruhi secara positif dan signifikan oleh kualitas produk dan citra merek. Citra merek juga dipengaruhi secara positif dan signifikan oleh kualitas produk. Hal ini berarti semakin bagus kualitas produk dan citra merek maka semakin tinggi pula loyalitas pelanggan pengguna produk telkomsel di Kota Bogor. Kemudian semakin bagus kualitas produk maka citra merek juga akan semakin bagus. Hasil penelitian juga menunjukkan bahwa citra merek memiliki fungsi sebagai mediator yang membentuk hubungan antara kualitas produk dengan loyalitas pelanggan. Citra merek juga memiliki pengaruh yang paling yang besar terhadap loyalitas pelanggan. Hal ini berarti bahwa untuk meningkatkan loyalitas pelanggan, maka kebijakan pertama yang harus dilakukan adalah meningkatkan citra merek.

\section{Saran}

Citra merek merupakna prioritas yang harus ditingkatkan karena memiliki pengaruh yang paling besar terhadap loiyalitas pelanggan. Hal ini dapat ditingkatkkan dengan meningkatkan kinerja dari produk telkomsel tersebut.

\section{Daftar Pustaka}

Bobâlcă, C., Gătej(Bradu), C., \& Ciobanu, O. (2012). Developing a Scale to Measure Customer Loyalty. Procedia Economics and Finance, 3(12), 623-628. https://doi.org/10.1016/s2212-5671(12)00205-5

Byrne, B. M. (2010). Structural Equation Modeling with AMOS. In Structural Equation Modeling with Amos Basic Concepts, Applications, and Programming (2nd ed.). https://doi.org/10.4324/9781410600219

Griffin, J. (2002). Customer Loyalty How to Earn It, How to Keep It. Kentucky: McGraw, Hill.

Hair, J. F. H., Hult, G. T., Ringle, C. M., \& Sarstedt. (2017). A Primer on Partial Least Squares Structural Equation Modelling (PLS-SEM). Los Angeles: Sage Publications.

Hengestu, N., \& Iskandar, D. A. (2017). Pengaruh Citra Merek Dan Harga Terhadap Loyalitas Pelanggan Air Minum Dalam Kemasan. Jurnal Riset Manajemen Dan Bisnis (JRMB) Fakultas Ekonomi UNIAT, 2(3), 363-372. https://doi.org/10.36226/jrmb.v2i3.70

Keller, K. L. (2013). Strategic Brand Management: Building, Measuring and Managing Brand Equity, 4th Edition. England: Pearson Education Limited.

Khoironi, T. A., Syah, H., \& Dongoran, P. (2018). Product Quality, Brand Image and Pricing to Improve Satisfaction Impact on Customer Loyalty. International Review of Management and Marketing, 8(3), 51-58.

Kotler, \& Keller. (2012). Manajemen Pemasaran (12th ed.). Erlangga.

Kusumasasti, I., Manajemen, J., Brawijaya, U., Hadiwidjojo, D., Manajemen, J., \& Brawijaya, U. (2014). Pengaruh Kualitas Produk dan Kualitas Pelayanan terhadap Loyalitas Pelanggan. Management Analysis Journal, 3(2), 123-129. https://doi.org/10.15294/maj.v3i2.3939

Lestari, A., \& Yulianto, E. (2018). Pengaruh Kualitas Produk Terhadap Loyalitas Pelanggan Dengan Kepuasan Pelanggan Sebagai Variabel Mediasi (Survei pada Pelanggan Citra Kendedes Cake \& Bakery Jl . S . Hatta B3 Kav. A, Kota Malang). Jurnal Administrasi Bisnis (JAB), 54(1), 74-81.

Lovelock, Christopher, Jochen Wirtz, \& Jacky Mussry. 2011. Pemasaran Jasa. edisi 7. Erlangga: Jakarta 
Ridho, M., \& Suharyono. (2017). Pengaruh Kualitas Produk terhadap Brand Image dan Dampaknya pada Kepuasan Pelanggan (Survei pada Pelanggan Kartu Prabayar Simpati, Kota Malang). Jurnal Administrasi Bisnis (JAB), 53(1), 124-131.

Sastha P, G. A. W. N., \& Wardhana, A. (2016). Pengaruh Citra Merek Terhadap Loyalitas Pelanggan ( Studi Pada Pelanggan Kartu Simpati Di Kota Denpasar ). E-Proceeding of Management :, 3, 1-5.

Schumacker, R. E., \& Lomax, R. G. (2010). A Beginner's Guide to Structural Equation Modeling (3rd ed.). Taylor \& Franciss Group.

Sihabudin. (2015). Pengaruh kualitas produk dan promosi terhadap citra merek handphone samsung. Jurnal Manajemen \& Bisnis, 1(1), 17-36.

Tjiptono, F. (2012). Strategi Pemasaran (3rd ed.). Yogyakarta: Andi Offset.

Wijayanto, I., \& Iriani, S. S. (2013). Pengaruh Citra Merek Terhadap Loyalitas Konsumen. Jurnal Ilmu Manajemen (JIM), l(3).

\section{Sumber internet}

www.telkomsel.com ， file:///C:/Users/LENOVO/Downloads/(FINAL)-TELKOMSEL_2018AR_Webver.pdf, diakses 13 januari 2020. 